\title{
ФОРМУВАННЯ ІНТЕЛЕКТУАЛЬНОЇ МОБІЛЬНОСТІ СТАРШОКЛАСНИКІВ У ПРОЦЕСІ НАВЧАННЯ
}

\author{
Попова О. В.
}

доктор педагогічних наук, професор, професор кафедри освітології та інноваційної педагогіки, Харківський національний педагогічний

університет імені Г. С. Сковороди, м. Харків, Україна

У статті представлено аналіз суті інтелектуальної мобільності як якості особистості старшокласника, запропоновано структуру досліджуваного поняття та охарактеризовано ї̈ компоненти, а також розглянуто засоби формування інтелектуальної мобільності старшокласників у прочесі навчання.

Ключові слова: інтелектуальна мобільність, компоненти інтелектуальної мобільності, формування, засіб, прочес навчання.

The article presents an analysis of the essence of intellectual mobility as a personality quality of high school students, proposes the structure of the concept and describes its components, as well as considers the means of forming intellectual mobility of high school students in the learning process.

Key words: intellectual mobility, components of intellectual mobility, formation, means, learning process.

Процеси прискореної модернізації та технологізації, що відбуваються в сучасному світі, зумовлюють потребу суспільства в такій людині, яка змогла б успішно справлятися зі складними завданнями і сучасного, і майбутнього цифрового світу, в особистості з високими інтелектуальними здібностями. Тільки інтелектуально мобільні особистості зможуть успішно адаптуватися за умов радикальних змін навколишнього світу. Не випадково в Концепції Нової української школи наголошено на необхідності забезпечення високого інтелектуально-творчого розвитку учнів [1].

У зв'язку з цим, одним із головних завдань системи освіти стає завдання формування й розвитку інтелектуальної мобільності у старшокласників, на яких в недалекому майбутньому буде покладатися відповідальність за вирішення стратегічних завдань у будь-якій сфері. Оскільки учні старших класів характеризуються більш високим ступенем усвідомленості і сформованістю в них мотивів до саморозвитку та самовдосконалення, вони можуть цілеспрямовано і $з$ цікавістю включитися 
у навчально-пізнавальну діяльність, спрямовану на розвиток у них інтелектуальної мобільності. Для того, щоб цей процес був успішним, учителеві необхідно розуміти суть і структуру означеної якості та володіти способами іï формування у старшокласників у процесі навчання.

Інтелектуальну мобільність розглядаємо як інтегроване особистісне утворення, що акумулює в собі інтелектуальні вміння, здібності та особистісні якості, які дають можливість здобувачеві освіти швидко віднаходити, обробляти й застосовувати інформацію, приймати рішення й оперативно діяти в стандартних і нестандартних ситуаціях, ефективно реалізовувати здобуті знання, обирати оптимальні способи виконання навчальних завдань.

Інтелектуальна мобільність особистості насамперед виявляється в інтелектуальних уміннях (аналітичних, синтетичних, порівняльних, абстрагувальних, систематизаційних, узагальнювальних [2]), основою яких є мисленнєві операції, які сприяють віднайденню, обробці й застосуванню інформації в процесі навчання.

Як доведено вченими, успішність формування інтелектуальної мобільності старшокласників значною мірою залежать від їхніх здібностей (когнітивних, креативних, оргдіяльнісних), що впливають на якість мислення учнів, зокрема на оригінальність, гнучкість, образність та спонтанність мисленнєвих операцій; стимулюють генерування різноманітних ідей тощо.

Особливості інтелектуальної мобільності старшокласників пов'язані 3 якісними змінами в їхній психічній діяльності: характерною рисою когнітивного розвитку цього віку є формально-логічне, формально-операційне мислення, що виявляється у виникненні в суб'єкта пізнан $\urcorner н я$ здатності до широких узагальнень, новому підході до розв'язання навчальних завдань, що полягає у спрямованості на структурування та групування фактів (комбінаторний аналіз), на встановлення причиннонаслідкових зв'язків та їх логічне обгрунтування й доказ [3, с.8].

Для організації процесу розвитку інтелектуальної мобільності учнів старших класів $є$ важливим визначення змісту структурних компонентів означеної якості.

Із огляду на сутнісні ознаки інтелекту та феномену «мобільність», у структурі інтелектуальної мобільності старшокласників виокремлюємо такі компоненти:

1) мотиваційно-цільовий, що відображає особисте ставлення до навчання, і виражений у цільових установках, інтересах і мотивах; 
2) когнітивно-змістовний, який включає сукупність теоретичних знань щодо інтелектуальних операцій та дій, реалізації інтелектуальнотворчого потенціалу;

3) процесуально-діяльнісний, заснований на комплексі інтелектуальних умінь і навичок;

4) рефлексивно-оцінний, що характеризує осмислення, самоаналіз і самооцінку власної навчально-пізнавальної діяльності та визначення на основі власного досвіду оптимальних методів і прийомів роботи.

Забезпечення інтелектуальної мобільності в навчальній діяльності старшокласників можливе тільки в тому випадку, якщо всі (суб) компоненти означеної якості працюватимуть як функціональна система, в якій кожен компонент грає свою взаємозалежну роль. Так, володіння спеціальними знаннями $є$ необхідною умовою для генерування креативних ідей, але для їх утілення та засвоєння знань необхідні концентрація уваги, додаток певних зусиль тощо. Отже, інтелектуальна мобільність учнів у навчальній діяльності закономірно буде залежати від рівня розвитку кожного (суб)компонента означеної якості.

До особистісних якостей, що характеризують інтелектуальну мобільність старшокласників, відносимо вольові (енергійність, рішучість, воля, активність, самостійність, діловитість; обачливість (здатність передбачати наслідки тих чи інших рішень); зосередженість і готовність до додатку зусиль (зосередженість на предметній області, ситуації, продукті; вибірковість; концентрація; завзятість; готовність до додатку зусиль); відкритість (до нового досвіду; експериментування) і толерантність до невизначеності (здатність переносити неоднозначність у сприйнятті чогось; готовність йти на ризик; готовність до труднощів; нонконформність/автономність); оптимальність (здатність віднайти результативний спосіб дії із найменшими за ттратами сил і ресурсів); здатність до самостійного й швидкого прийняття рішень.

3 огляду на вищезазначене можна стверджувати, що феномен інтелектуальної мобільності доцільно розглядати як інтегративну характеристику особистості, що визначається єдністю когнітивного (пізнавального), емоційно-вольового, мотиваційно-особистісного та операційнодіяльнісного параметрів, які підлягають розвитку в цілеспрямовано організованих умовах навчання.

Аналіз психолого-педагогічних досліджень (М. Лазарєв, О. Лазарєва, В. Лозова, В. Моляко, В. Паламарчук та інші), результати власних 
наукових розвідок та вивчення масової шкільної практики дали підстави визначити ефективні засоби (форми, методи, технології) формування інтелектуальної мобільності старшокласників, як-от:

- проблемне, евристичне навчання;

- навчально-дослідна робота;

- проєктна діяльність;

- активні (метод прогнозування, метод відсіювання, метод узагальнення ідей, «кути», «п’ять слів - три слова», квести та ін.) та інтерактивні (дискусійні — метод «ПРЕС», «Займи позицію», «Зміни позицію», «Неперервна шкала думок» (континіум, нескінченний ланцюжок), «Оцінювальна дискусія», «Дебати» тощо); ситуативне моделювання, імітаційні ігри, мозковий штурм (брейнстормінг), кластери (порівняльні діаграми, пазли), круглий стіл, метод проєктів, «barcamp», «сіндикат», проблемно-рефлексивний полілог та ін.) методи;

- сучасні технології навчання, у тому числі ІКТ (технологія емоційного інтелекту, технологія туду-лист, swod-аналіз, кейс-технології та ін.).

Застосування вказаних засобів вимагають від учнів інтелектуальної напруги і дають можливість:

- навчати здобувачів освіти критично мислити, розвивати їхню пізнавальну активність;

- сприяти знаходженню старшокласниками нових для себе рішень на основі оволодіння методами й механізмами евристичної праці;

- застосовувати знання (інформацію) для оперативного прийняття рішень і брати на себе відповідальність за їх реалізацію;

- сприяти прояву здобувачами освіти дослідницької активності в процесі вирішення навчальних завдань різних видів і пошуку результату оригінальними способами;

- виховувати в учнів емоційний інтелект.

\section{Список використаних джерел:}

1. Нова українська школа. Концептуальні засади реформування середньої школи. Міністерство освіти та науки України, 2016. URL: https://mon.gov.ua/ storage/app/ media/zagalna\%20serednya/nova-ukrainska-shkola-compressed.pdf

2. Паламарчук В.Ф. Техне Інтелектус (технологія інтелектуальної діяльності учнів) : посіб. для вчителів. Київ, 1999. 89 с.

3. Хорунжа Л. А. Формування інтелектуальної мобільності старшокласників у навчальному процесі загальноосвітньої школи : автореф. дис. ... канд. пед. наук : 13.00.09 «Теорія навчання». Харків, 2009. 20 с. 